\title{
Modellering van nukleofiliese aromatiese substitusiereaksies in kinoksalien-verwante sisteme
}

\author{
Outeurs: \\ Hendrik J van der Poll \\ I Cukrowski \\ Affiliasie: \\ Departement Chemie, \\ Universiteit van Pretoria, \\ Privaatsak X20, Hatfield, \\ 0028, Suid-Afrika \\ Korresponderende outeur: \\ Hendrik van der Poll \\ E-pos:vdpolhj@gmail.com \\ Hoe om hierdie artikel aan \\ te haal: \\ Hendrik J van der Poll, \\ I Cukrowski, Modellering \\ van nukleofiliese aromatiese \\ substitusiereaksies in kinok- \\ salien-verwante sisteme, \\ Suid-Afrikaanse Tydskrif \\ vir Natuurwetenskap en \\ Tegnologie 39(1) (2020). \\ https://doi.org/10.36303/ \\ SATNT.2020.39.1.831 \\ Kopiereg: \\ (C) 2020. Authors. \\ Licensee: Die Suid- \\ Afrikaanse Akademie vir \\ Wetenskap en Kuns. \\ Hierdie werk is onder \\ die Creative Commons \\ Attribution License \\ gelisensieer.
}

\begin{abstract}
Modelling of nucleophilic aromatic substitution reactions in Quinoxaline derivative systems: This study focused on the quantum mechanical modelling of nucleophilic aromatic substitution reactions of Quinoxaline systems. The results gave insight into why certain reaction routes, which were synthetically unsuccessful, failed. The study also aimed to provide possible solutions to failure. In future, other types of computer modelling could be done.
\end{abstract}

Kinoksalienmolekules en hul verwante sisteme het onlangs groot aftrek in die mediese wetenskappe begin kry, spesifiek vir hul gebruik in Farmakologie. Dus is daar groot nut in die uitbreiding van huidige gebruikte sintetiese roetes. Die huidige gebruikte roetes laat veel te wense oor, aangesien hulle lae opbrengste lewer en in die meeste gevalle as "nie-werkende" sintetiese roetes beskou word. Hierdie studie beskou hierdie reaksies en hul meganismes op sowel fundamentele, berekende, as kwantummeganiese vlak. Guassian $\odot 09$ en 16 sagteware is gebruik om die modellering te doen. Tans is daar nog geen rekenaarmodellering van hierdie tipe sisteme gedoen nie, dus is 'n groot veld beskikbaar wat ondersoek kan word.

Die huidige sintetiese roetes is eerstens gemodelleer soos wat dit tans in die laboratoriums van die Universiteit van Limpopo uitgevoer word. Hierdie sintetiese navorsing het ' $n$ wye verskeidenheid van reagense getoets, maar nooit redes verskaf hoekom sekere reagense nooit produkte oplewer nie. Daar is vasgestel dat die reaksie in twee stappe plaasvind. In die eerste stap vorm 'n nie-aromatiese tussenganger ('n nukleofiliese aanval van 'n nukleofiel op ' $n$ $\alpha$-koolstof) en in die tweede stap word ' $n$ aromatiese produk gevorm. Die reaksie word ' $n$ nukleofiliese substitusie genoem, omdat ' $n$ nukleofiel ' $n$ waterstofatoom of ' $n$ sogenaamde $\alpha$-koolstof vervang. Die eerste stap is gekarakteriseer as 'n stap met hoë energie in sekere gevalle, terwyl dit laag in ander is. Dit het 'n eerste aanduiding verskaf waarom die reaksies so sukkel om plaas te vind. Vervolgens is bevind dat suurstof die groot dryfkrag agter die tweede stap van die reaksiemeganisme is. Die suurstof help die nie-aromatiese tussenganger om terug te keer na 'n aromatiese produk. Daar is ook waargeneem dat die suurstof, hoewel belangrik in sekere gevalle, wel die tussenganger kan laat opbreek terug na die aanvanklike reagense. Om die probleme met suurstof in die tweede stap aan te spreek, en dus eerder in 'n inerte omgewing te werk, is twee ander moontlike roetes oorweeg, naamlik die byvoeging van chloor of broom. Die eerste resultate van die broomopsie was belowend, aangesien dit in die gevalle waar suurstof die tussenganger opbreek, wel produkte verskaf het.

Hoewel die studie nog in die beginfase is, is daar reeds noemenswaardige resultate verkry waarmee die navorsing verder uitgebrei kan word. Vervolgens gaan gekyk word na die effek van verskillende oplosmiddels op die aktiveringsenergie van die sisteem. Daar kan ook ander tipe berekeninge (anders as wat moontlik is met die Gaussiese sagteware) gedoen word op die sisteme, soos byvoorbeeld die kwantumteorie van atome in molekules (QTAIM) wat inligting kan verskaf oor die Coulomb-interaksies van die atome in die sisteem. Die interaksies van die molekulêre orbitale van die reagense wat gebruik is, kan ook ondersoek word om oriëntasieprobleme aan te spreek.
Nota: 'n Seleksie van referaatopsommings: Studentesimposium in die Natuurwetenskappe, 31 Oktober - 1 November 2019 Universiteit van die Vrystaat. Reëlingskomitee: Prof Rudi Pretorius (Departement Geografie, Universiteit van Suid-Afrika); Dr Hertzog Bisset (Suid-Afrikaanse Kernenergie-korporasie; Dr Ernie Langner (Departement Chemie, Universiteit van die Vrystaat) en Dr Wynand Nel (Departement Rekenaarwetenskap en Informatika, Universiteit van die Vrystaat). 